\title{
Determination of relevant endpoints to evaluate the in vivo barrier function in cutaneous health
}

\author{
Determinação de "endpoints" relevantes para a avaliação in vivo da função "barreira" na \\ saúde cutânea
}

\author{
Emília Alves $^{1}$, Patrícia Rijo ${ }^{1}$, Luís Monteiro Rodrigues ${ }^{1,2}$, Catarina Rosado ${ }^{1}$ \\ ${ }^{1}$ CBIOS - Universidade Lusófona's Research Center for Health Science and Technologies, \\ Campo Grande, 376, 1749-024, Lisboa, Portugal \\ ${ }^{2}$ Dep. Pharmacol Sciences - Universidade de Lisboa (Faculty of Pharmacy) \\ Email: catarina.rosado@ulusofona.pt
}

\begin{abstract}
This work aims to identify endpoints to evaluate the in vivo barrier function of the skin by noninvasive methods in healthy and atopic individuals, thus contributing to the consolidation of methodologies that can be employed in later studies of the action on skin health of different health products and food supplements. In this context, the cutaneous aggression induction model using sodium lauryl sulphate (SLS) was used, followed by evaluation of transepidermal water loss (TEWL) and vascular blood flow of the dermis by colorimetry and laser Doppler flowmetry $(\mathrm{LDF})$, in a group of healthy volunteers $(\mathrm{n}=15)$ and in a group with atopic dermatitis $(\mathrm{n}=5)$. The healthy individuals presented a basal TEWL slightly superior to the atopic group. In skin without intervention, baseline values did not change, 24 hours after induction of irritation, in both groups $(p<0.05)$. In the aggressed skin, in the same period, values presented a higher variation than that of the control zone $(p<0.05)$, being greater in the atopic than in the healthy group. Results confirm that measurement of TEWL after SLS aggression allows a good assessement of skin barrier function in both healthy and atopic subjects and suggest that erythema may be a measure of support for the robustness of the results.
\end{abstract}

Keywords: cutaneous health, TEWL, sodium lauryl sulphate

\section{Resumo}

Este estudo pretende identificar endpoints para avaliar in vivo a função de barreira da pele, por métodos não invasivos, em indivíduos com atopia e em saudáveis, contribuindo assim para a consolidação de metodologias de estudo que possam ser depois aplicadas na avaliação da ação na saúde da pele de diferentes produtos de saúde e suplementos alimentares. Neste contexto, usou-se o modelo de indução de agressão cutânea com lauril sufato de sódio (LSS) seguido de avaliação da perda transepidérmica de água (PTEA) e do fluxo sanguíneo vascular da derme, por colorimetria e por fluxometria de laser Doppler (FLD), num grupo de voluntários saudáveis $(n=15)$ e num grupo de atópicos $(n=5)$. Os voluntários saudáveis apresentaram uma PTEA basal ligeiramente superior aos atópicos. Na pele sem intervenção, os valores basais não sofreram alteração, $24 \mathrm{~h}$ após indução da irritação, em ambos os grupos $(\mathrm{p}<0,05)$. Na pele tratada com LSS, no mesmo período, os valores apresentaram uma variação maior do que na zona controle $(\mathrm{p}<0,05)$, sendo maior no grupo atópico do que no grupo saudável. Os resultados confirmam que a avaliação das alterações cutâneas após agressão com LSS, por medição da PTEA permite uma boa apreciação da função de barreira da pele, quer em voluntários saudáveis quer em atópicos, e sugerem que a medição do eritema por colorimetria pode ser uma avaliação de suporte à robustez deses resultados.

Palavras-Chave: barreira cutânea, PTEA, lauril sulfato de sódio 


\section{Introduction}

The skin is a functionally complex organ made up of three interdependent layers, the epidermis, the dermis and the hypodermis ${ }^{[1]}$. Its relationship with other organs contributes to both balance with the external environment and internal balance, enhancing its function beyond the coating and protective properties of the body ${ }^{[2]}$.

The epidermis provides a physical and functional barrier to the human body and its outermost layer, the stratum corneum (SC), ensures the integrity and hydration of the skin ${ }^{[2]}$. The SC acts as a homogeneous membrane for the diffusion of water and is involved in the regulation of the loss of water from the body to the atmosphere, termed transepidermal water loss (TEWL). TEWL is defined as the passive diffusion of water through the epidermis, i.e., the constitutive loss of skin water vapor in the absence of sweat glandular activity [3]. A low TEWL is characteristic of intact and healthy skin, while an elevated TEWL indicates that the skin barrier function is compromised ${ }^{[4,5]}$.

Atopic dermatitis (AD) is a chronic inflammatory skin disease associated with an exacerbated skin response to environmental agents and characterized by pruritic lesions with typical dryness and morphology. Defects in the cutaneous barrier are considered as an initial step in the development of $\mathrm{AD}^{[6]}$. When the barrier is compromised, the penetration of substances may stimulate keratinocytes and Langerhans cells to produce mediators that are involved in the inflammatory response ${ }^{[7]}$.

As mentioned, TEWL can be measured non-invasively and is considered a parameter of interest to evaluate skin barrier function ${ }^{[4]}$. In some studies conducted in the context of the evaluation of cutaneous conditions, such as $\mathrm{AD}$, the affected skin regions show higher TEWL compared to normal skin, meaning lower water retention capacity ${ }^{[2,4,5]}$. However, not all papers report these types of results . In addition, the limitations of the methodology are known, especially since a tenuous correlation was found between skin damage and TEWL variations ${ }^{[3,8]}$. Thus, the competence of the barrier can be assessed by measuring the basal TEWL and/or by observing the recovery of TEWL after rupture of the cutaneous barrier ${ }^{[9]}$.

Contact dermatitis is the inflammatory reaction of the skin, whose main clinical manifestation is eczema. Substances that can cause eczema in any skin type are considered primary irritants ${ }^{[10]}$. These may be used experimentally in certain circumstances, but it should be ensured that they do not cause systemic toxicity, sensitization, carcinogenesis, or cosmetic inconvenience.

\section{Introdução}

A pele é um órgão funcionalmente complexo constituído por três camadas interdependentes, a epiderme, a derme e a hipoderme ${ }^{[1]}$. A sua relação com outros órgãos, contribui quer para o equilíbrio com o ambiente externo quer para o equilíbrio interno, elevando a sua função para além das propriedades de revestimento e proteção do corpo ${ }^{[2]}$.

A epiderme proporciona uma barreira física e funcional ao corpo humano e a sua camada mais externa, o estrato córneo (EC), assegura a integridade e a hidratação da pele ${ }^{[2]}$. O EC está envolvido na regulação da perda de água do organismo para a atmosfera, designada por perda transepidérmica de água (PTEA) que se define como a difusão passiva da água através da epiderme, i.e., a perda constitutiva de vapor de água da pele na ausência de atividade glandular sudorípara ${ }^{[3]}$. Uma PTEA baixa é característica de uma pele intacta e saudável, enquanto uma PTEA elevada indica que a função de barreira está comprometida ${ }^{[4,5]}$

A dermatite atópica (DA) é uma doença inflamatória crónica da pele associada a uma resposta cutânea exacerbada aos agentes ambientais e caracterizada por lesões pruríticas com secura e morfologia típica. Defeitos na barreira cutânea são considerados como um passo inicial no desenvolvimento de DA ${ }^{[6]}$. Quando a barreira está comprometida, a penetração de substâncias pode estimular os queratinócitos e as células de Langerhans para produzir mediadores que estão envolvidos na resposta inflamatória ${ }^{[7]}$.

Como referido, a PTEA pode ser medida de forma não invasiva sendo considerada um parâmetro interessante para avaliar a função de barreira cutânea ${ }^{[4]}$. Em alguns estudos efectuados no contexto da avaliação de patologias cutâneas, como a DA, as regiões da pele afetadas mostram maior PTEA em comparação com a pele normal, ou seja, menor capacidade de retenção de água $[2,4,5]$. No entanto, nem todos os trabalhos mostram este tipo de resultados. Adicionalmente, são conhecidas as limitações da metodologia, nomeadamente por ter sido encontrada uma correlação ténue entre danos infligidos à pele e variações da PTEA ${ }^{[3,8]}$. Assim, a competência da barreira poderá ser avaliada pela medição da PTEA basal e/ou através da observação da recuperação de PTEA após a ruptura da barreira cutânea ${ }^{[9]}$.

A dermatite de contacto é uma reação inflamatória da pele, cuja principal manifestação clínica é o eczema. As substâncias que podem causar eczema em qualquer tipo de pele, são considerados irritantes primários ${ }^{[10]}$. Estes podem ser usados experimentalmente em determinadas circunstâncias, devendo no entanto garantir-se que não 
Additionally, such substance should have no extreme $\mathrm{pH}$ and be well defined chemically ${ }^{[11]}$.

The surfactant Sodium Lauryl Sulfate (SLS) is the most commonly used substance in the experimental induction of contact dermatitis by primary irritancy. Although most clinically observed cases of irritant contact dermatitis occur in the hands, it has been shown that the forearm provides reliable and reproducible results and is therefore a good alternative for experimental tests ${ }^{[12]}$. Different non-invasive methods can be used to evaluate the cutaneous response to the irritant, distinguished by the type of physiological phenomenon analyzed, or by the quantification technique. In assessing the skin barrier function experimentally induced by irritation, the combination of TEWL measurements and another noninvasive method is recommended to obtain more robust results ${ }^{[13]}$. Skin exposure to SLS causes changes in the skin barrier and hemodynamic changes that are manifested by differentiated red blood cell perfusion and increased local microvascular blood flow. Two dermal bioengineering methodologies allow the quantitative evaluation of vascular dermis blood flow: laser Doppler flowmetry (LDF) and colorimetry ${ }^{[14-17]}$.

The majority of the studies conducted on the action of health products and food supplements in skin condition are based only on scoring rates of lesions in the form of eczema. This work aims to identify endpoints to evaluate in vivo in healthy and atopic individuals the cutaneous health using noninvasive methods, enabling a later study to the consolidation of methodologies for efficacy assessment of these products. Thus, an assessment was made of the applicability in this context of the model of induction of cutaneous aggression using SLS followed by evaluation by cutaneous bioengineering methodologies.

\section{Materials and methods}

A convenience sample was used in this study. The work was conducted in accordance with the principles of the Helsinki Declaration. After informed consent, 20 participants of both sexes were included in the study. Of these participants, 15 were considered healthy with no history of cutaneous disease, aged between 18 and 45 years (mean age $25.33 \pm 7.29$ years), and 5 were with self-reported atopy, aged between 18 and 50 years (mean age $26.20 \pm 13.50$ years).

Healthy participants had no visible cutaneous lesions and no past or present record of dermatological disease causam toxicidade sistémica, sensibilização, carcinogénese ou inconveniência cosmética, que não possuem $\mathrm{pH}$ extremo e que são bem definidos quimicamente ${ }^{[1]}$. O surfactante Lauril Sulfato de Sódio (LSS) é a substância utilizada com mais frequência na indução experimental da dermatite de contacto por irritante primário. Embora a maioria dos casos clinicamente observados de dermatite de contato por agente irritante ocorra nas mãos, foi demonstrado que o antebraço fornece resultados confiáveis e reprodutíveis sendo, portanto, uma boa alternativa para estudos experimentais ${ }^{[12]}$.

Podem ser utilizados diferentes métodos não invasivos para avaliar a resposta cutânea ao irritante, distinguindo-se quer pelo tipo de fenómeno fisiológico analisado, quer pela técnica de quantificação. Na avaliação da função de barreira da pele induzida experimentalmente por irritação, a combinação das medições de PTEA e de outro método não invasivo é recomendada para obter resultados mais robustos ${ }^{[13]}$. A exposição da pele ao LSS provoca alterações à barreira cutânea e alterações hemodinâmicas que se expressam pela perfusão diferenciada dos eritrócitos e aumento do fluxo sanguíneo microvascular local. Duas metodologias de bioengenharia cutânea permitem avaliar quantitativamente variações do fluxo sanguíneo vascular da derme: a fluxometria por laser Doppler (FLD) e a colorimetria ${ }^{[14-17]}$. A maioria dos estudos da ação de suplementos alimentares e produtos de saúde sobre a pele baseiam-se em sistemas de scoring da severidade de eczema. Este trabalho pretende identificar endpoints para avaliar in vivo em indivíduos com atopia e em saudáveis o impacto na saúde cutânea, por métodos não invasivos, permitindo um estudo posterior para a consolidação de metodologias de avaliação da eficácia destes produtos. Assim, foi feita uma avaliação da aplicabilidade neste contexto do modelo de indução de agressão cutânea recorrendo ao LSS seguido de avaliação por metodologias de bioengenharia cutânea.

\section{Materiais e Métodos}

Foi utilizada neste estudo uma amostra de conveniência. O trabalho foi conduzido de acordo com os princípios da Declaração de Helsínquia. Após consentimento informado, 20 participantes de ambos os sexos, 15 dos quais saudáveis sem historial de doença cutânea, com idade entre os 18 e os 45 anos (idade média 25,33 \pm 7,29 anos) e 5 dos quais com atopia autoreportada, com idade entre os 18 e os 50 anos (idade média 26,20 \pm 13,50 anos), foram incluídos no estudo.

Os participantes saudáveis, não apresentavam lesões cutâneas visíveis e nenhum registo passado ou presen- 
or atopy. Atopic participants had no visible skin lesions in the study area. All participants were advised not to use moisturizers or other cosmetic products in the test area, 48 hours before the start of the test and during the test period ( 2 days).

The impact on the skin barrier function caused by SLS application was evaluated by the measurement of transepidermal water loss (TEWL) and vascular blood perfusion of the dermis. To quantify the latter, measurements of erythema by colorimetry and blood perfusion using laser Doppler flowmetry (LDF) were used.

TEWL measurements $\left(\mathrm{g} / \mathrm{m}^{2} / \mathrm{h}\right)$ were performed using a Tewameter ${ }^{\circledR}$ TM300 (CK Electronics, Germany). Measurements of erythema were performed with a Chroma Meter CR300 (Minolta, Japan). Color was expressed in the $\mathrm{L}^{*} \mathrm{a} * \mathrm{~b}$ system, where skin erythema is indicated by $\mathrm{a}^{*}{ }^{[16]}$. Measurements of laser Doppler flowmetry were performed with a Laser Doppler Flowmeter ${ }^{\mathbb{B}}$ PF5010 (Perimed, Denmark). Blood flow measurements were expressed in arbitrary perfusion units (PU). For each parameter, two consecutive measurements were performed, by test zone, under controlled temperature and humidity conditions (ambient temperature $21 \pm 1{ }^{\circ} \mathrm{C}$, relative humidity of $40-60 \%$ ), according to the guideline recommendations ${ }^{[15,16,18]}$. The volunteers rested for at least 20 minutes in these conditions before measurements.

Two zones - a control zone and a SLS zone - were evaluated in the ventral part of the forearm, randomly distributed, in each participant.

The basal measurements were performed at time t0 in both zones, after which a occlusve chamber adhesive (Finn Chambers, USA) was applied to the treated zone with $100 \mu \mathrm{l}$ SLS (purity> 99\%; Sigma Chemical Co., St. Louis, MO, USA) in 1\% aqueous solution. This adhesive was kept in contact with the skin for 24 hours. After this period ( $\mathrm{t} 24 \mathrm{~h}$ ) the measurements were repeated, and the SLS zone was evaluated 1 hour after removal of the adhesive.

To reduce the impact of intra and interindividual variability the results were analyzed as the ratio between the value obtained at the end of the study (t24) and the baseline value $(\mathrm{t} 0)$.

For the statistical analysis of the continuous variables a non-parametric test was used, Mann Whitney test. The significance level was established at $\mathrm{p}<0.05$. te de doença dermatológica ou atopia. Os participantes atópicos, não apresentavam lesões cutâneas visíveis na área de estudo. Todos os participantes foram aconselhados a não utilizar cremes hidratantes ou outros produtos cosméticos na zona de teste, $48 \mathrm{~h}$ antes do inicio do ensaio e durante o período de realização do mesmo (2 dias).

O impacto na função de barreira cutânea causado pela aplicação de LSS foi avaliado pela medição da perda transepidérmica de água (PTEA) e pelo fluxo sanguíneo vascular da derme. Para quantificação deste último foram usadas medições de eritema por colorimetria e da perfusão sanguínea por fluxometria por laser Doppler (FLD).

As medições de PTEA $\left(\mathrm{g} / \mathrm{m}^{2} / \mathrm{h}\right)$, foram efetuadas usando um Tewameter ${ }^{\circledR}$ TM300 (CK Electronics, Alemanha). As medições de eritema foram realizadas com um Chroma Meter CR300 (Minolta, Japão) usando o sistema CIE L*a*b, onde o eritema da pele é indicado por $\mathrm{a}^{*}$ ${ }^{[16]}$. As medições FLD foram realizadas com um Laser Doppler Flowmeter ${ }^{\circledR}$ PF5010 (Perimed, Dinamarca) e expressas em unidades arbitrárias de perfusão (UP). Para cada parâmetro, foram realizadas 2 medições consecutivas, por zona de teste, sob condições de temperatura e humidade controladas (temperatura ambiente $21 \pm 1^{\circ} \mathrm{C}$; humidade relativa de $40-60 \%$ ), de acordo com as recomendações das guidelines ${ }^{[15,16,18]}$. Os voluntários descansaram pelo menos 20 minutos, nestas condições, antes das medições.

Foram avaliadas duas zonas na parte ventral do antebraço, distribuídas de forma aleatória, em cada participante: Zona controlo e Zona LSS.

As medições basais foram efetuadas no tempo t0, em ambas as zonas, após o que foi aplicado na zona tratada um adesivo com câmara oclusiva (Finn Chambers, USA) com $100 \mu$ de LSS (pureza> 99\%; Sigma Chemical Co., St Louis, MO, EUA) em solução aquosa a 1\%. Este adesivo foi mantido em contacto com a pele por 24 horas. Após esse periodo ( $\mathrm{t} 24 \mathrm{~h})$ repetiram-se as medições, sendo a zona LSS avaliada 1 hora após remoção do adesivo.

Para diminuir o impacto da variabilidade intra e interindividual os resultados foram analisados como o rácio entre o valor obtido no final do estudo (t24) e o valor basal ( $\mathrm{t} 0)$.

Para a análise estatística das variáveis continuas utilizou-se um teste não paramétrico, teste de Mann Whitney. Um nível de significância inferior a 0,05 foi considerado. 


\section{Results}

Baseline TEWL values obtained in the forearm were compared, and the healthy group presented a slightly higher baseline TEWL than the atopic group, but with a greater dispersion. The differences found were not statistically significant $(\mathrm{p}=0.553)$ (Figure 1$)$.

\section{Resultados}

Compararam-se os valores de PTEA basal do antebraço, verificando-se que o grupo de saudáveis apresentou uma PTEA basal ligeiramente superior ao grupo dos atópicos, mas com uma dispersão maior. As diferenças encontradas não foram estatisticamente significativas $(p=0,553)$ (Fig.1).

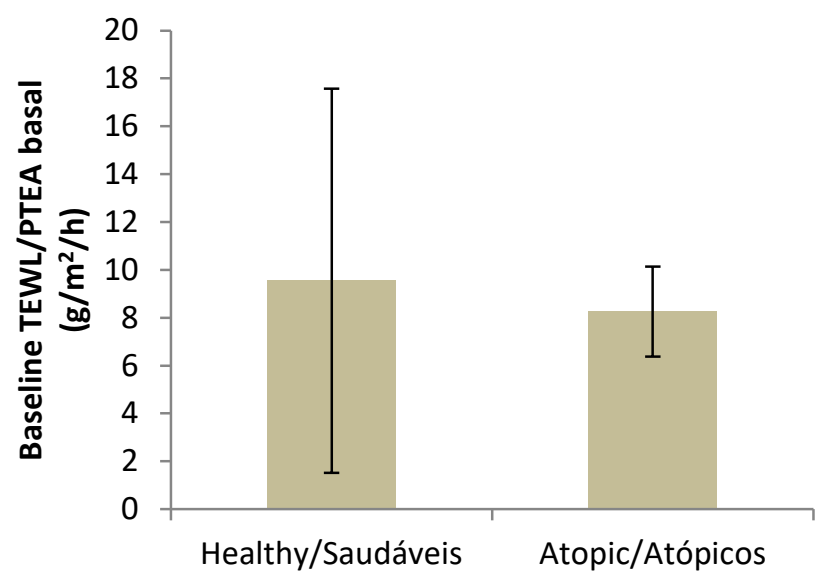

Figure 1 / Figura 1 - Baseline TEWL, in the healthy group and in the atopic group (mean $\pm \mathrm{SD}$ ), $\mathrm{p}=0.553$ / PTEA basal, no grupo de saudáveis e no grupo de atópicos (média $\pm \mathrm{DP}), \mathrm{p}=0,553$.

The mean values of the variation between $t 0$ and $t 24$ for TEWL, a* and blood perfusion in the two test zones were determined in healthy volunteers and in the atopic group (Table 1 and Figure 2).

As expected, in the skin without intervention (control zone) baseline values of TEWL, a* and LDF did not change after 24 hours in both the healthy and atopic volunteers, with values close to unity. These results indicate the suitability of the methodology.

In the SLS zone, 24 hours after induction of irritation, the variation of TEWL, a* and LDF presented values significantly higher than those of the control zone. This variation was greater in atopic than healthy volunteers and that the differences recorded between the two zones were statistically significant for each group. The blood perfusion values presented a very high dispersion in both groups.
Foram determinados os valores médios da variação entre t0 e t24 para PTEA, a* e perfusão sanguínea nas duas zonas de teste, no grupo de voluntários saudáveis e no grupo atópico (Tabela 1 e Figura 2).

Como esperado, na pele sem intervenção (zona de controlo) os valores basais de PTEA, a* e FLD não sofreram alteração após $24 \mathrm{~h}$, tanto no grupo de voluntários saudáveis, como no dos atópicos, tendo por isso sido obtidos valores de rácio próximos da unidade. Estes resultados são indicadores da adequabilidade da metodologia desenvolvida.

Na zona LSS, 24h após indução da irritação, os resultados de PTEA, a* e UP de FLD apresentaram valores significativamente mais elevados do que na zona de controlo (Tabela 1). Deve ser notado que essa variação foi um pouco maior nos voluntários atópicos do que em saudáveis embora as diferenças registadas entre as duas zonas não tenham sido estatisticamente significativas. Os valores de perfusão sanguínea apresentaram uma dispersão muito elevada, em ambos os grupos.

\section{Discussão e Conclusão}

A DA é uma patologia cutânea de etiologia ainda não completamente esclarecida. Têm sido estudadas inúmeras abordagens para esta patologia, terapêuticas e não 
Table 1/ Tabela 1 - Variation ( $\mathrm{t} 24$ / $\mathrm{t} 0$ ) in TEWL, a* and LDF, in atopic and healthy subjects / Variação (t24/t0) em PTEA, a* e FLD, em atópicos e saudáveis.

\begin{tabular}{cllll}
\hline & & $\begin{array}{l}\text { Control zone/ } \\
\text { Zona Controlo } \\
\text { Mean } \pm \mathrm{SD} /\end{array}$ & $\begin{array}{l}\text { SLS zone/ } \\
\text { Zona LSS } \\
\text { mean } \pm \mathrm{SD} /\end{array}$ & p-value \\
& & $0.99 \pm 0.21$ & $3.90 \pm 0.41$ & 0.008 \\
& TEWL/PTEA & & \\
\hline $\begin{array}{c}\text { Atopic/Atópicos } \\
(\mathbf{n = 5 )}\end{array}$ & $\begin{array}{l}\text { Erythema/Eritema } \\
\left(\mathrm{a}^{*}\right)\end{array}$ & $1.01 \pm 0.08$ & $1.51 \pm 0.30$ & 0.008 \\
& LDF/FLD & $0.82 \pm 0.22$ & $4.71 \pm 3.10$ & 0.008 \\
& TEWL/PTEA & $0.90 \pm 0.26$ & $3.41 \pm 1.10$ & 0.000 \\
$\begin{array}{c}\text { Healthy/Saudáveis } \\
(\mathbf{n = 1 5})\end{array}$ & $\begin{array}{l}\text { Erythema/Eritema } \\
\left(\mathrm{a}^{*}\right)\end{array}$ & $1.00 \pm 0.12$ & $1.29 \pm 0.26$ & 0.001 \\
& LDF/FLD & $0.75 \pm 0.17$ & $3.03 \pm 3.25$ & 0.000 \\
\hline
\end{tabular}

Significance level $<0.05$ / Nível de significância $<0,05$

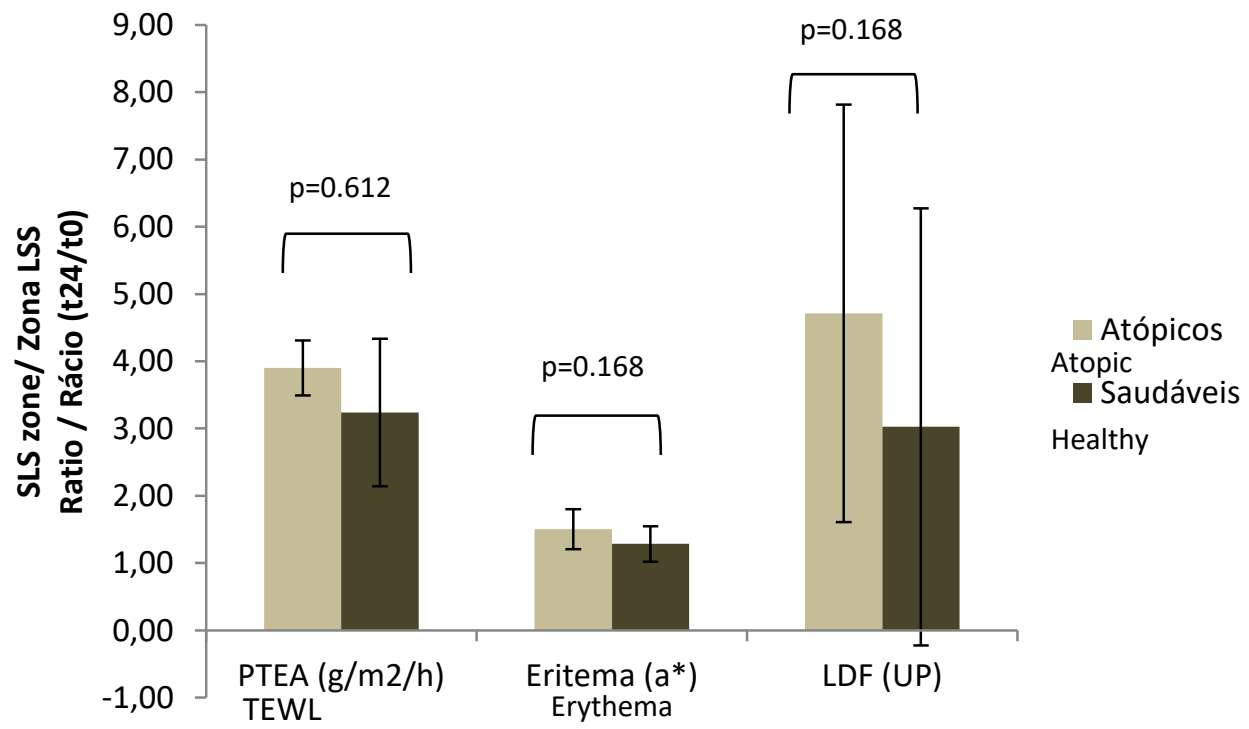

Figure 2 / Figura 2 - Variation ( $\mathrm{t} 24 / \mathrm{t} 0$ ), at SLS zone, in TEWL, a* and LDF, between atopic and healthy volunteers (mean \pm SD) / Variação (t24/t0), na zona LSS, em PTEA, a* e FLD, entre voluntários atópicos e saudáveis (média $\pm D P$ ) 
of the most recent being intervention by probiotic supplementation. There are numerous reports in the literature of a compromised molecular composition in the epidermis of individuals with $\mathrm{AD}$, especially in a protein critical for the integrity of the stratum corneum - filaggrin ${ }^{[19]}$. However, most of the studies conducted on the efficacy of this strategy have been based only on improved scoring rates of lesions in the form of eczema ${ }^{[20]}$, which is perhaps behind the poor correlations found between the use of probiotics and improvements in skin health.

There are different methods to evaluate skin barrier function in vivo as a quantitative parameter applied to the characterization of the evolution of cutaneous pathologies. The most commonly used is the direct measurement of the TEWL, but the evaluation of the impact on the TEWL by action of primary irritant can be an interesting approach ${ }^{[9]}$, especially considering the limitations of the methodology previously described.

The results obtained in this study for the baseline TEWL in atopic and healthy volunteers confirm the interest of this approach, since no statistically significant differences were found between them. In addition, the average values recorded in the healthy group are slightly higher, contrary to what would be expected. It should, however, be noted that these results were obtained in groups with quite different numbers of volunteers. In this study we found statistically significant differences between the basal state of the skin and after intervention with a primary irritant, both in healthy volunteers and in atopics, in all endpoints tested. However, the LDF values obtained, following the same trend as the other parameters, showed a high dispersion, which suggests a greater interference of the intra and intervariability effects on the participants, as well as the limitations of the methodology itself. It is worth noting the much lower variability of the results obtained with colorimetry, which indicates that this methodology may be more advantageous in the evaluation of erythema.

In a study comparing the results obtained with LDF and TEWL in healthy volunteers, it was observed that only with higher concentrations of SLS did the increase of LFD values occur ${ }^{[21]}$. This fact was justified by the fact that the damage caused by the surfactant in the epidermal barrier, by altering the lipids and proteins of the stratum corneum, occurs faster than the inflammatory and vascular response. However, when the barrier is more severely damaged by high concentrations of SLS, the inflammatory response is more intense, and it is then possible to verify the changes by flowmetry ${ }^{[21]}$. In the present study, the comparison between the mean values obtained in the present study of TEWL, erythema quantified by colorimetry $\left(a^{*}\right)$ and LDF allows us terapêuticas, sendo uma das mais recentes a intervenção por suplementação com probióticos. Encontram-se inúmeros relatos na literatura de uma composição molecular comprometida na epiderme de indivíduos com DA, especialmente numa proteína crítica para a integridade da barreira do estrato córneo- a filagrina ${ }^{[19]}$.No entanto, a maioria dos estudos realizados sobre a eficácia desta estratégia tem sido baseada apenas na melhoria de índices de scoring das lesões sob a forma de eczema [20], o que talvez esteja por trás das pobres correlações encontradas entre o uso de probióticos e melhorias da saúde cutânea.

Existem diferentes métodos para avaliar in vivo a função de barreira da pele como parâmetro quantitativo aplicado à caracterização da evolução de patologias cutâneas. O mais usado consiste na medição directa da PTEA, mas a avaliação do impacto na PTEA por ação de agente irritante primário pode ser uma abordagem interessante ${ }^{[9]}$, sobretudo tendo em conta as limitações da metodologia descritas anteriormente. Os resultados obtidos neste estudo para a PTEA basal nos voluntários atópicos e sem esta patologia confirmam o interesse desta abordagem, já que não se encontraram diferenças estatisticamente significativas entre estes. Adicionalmente, a média de valores registados no grupo saudável é ligeiramente superior, contrariamente ao que seria de esperar. Deve, no entanto, ser notado que estes resultados foram obtidos em grupos com números bastante diferentes de voluntários.

Neste estudo foram encontradas diferenças estatisticamente significativas entre o estado basal da pele e após intervenção com um irritante primário, quer em voluntários saudáveis quer em atópicos, em todos os endpoints testados. No entanto, os valores de FLD obtidos, tendo seguido a mesma tendência dos outros parâmetros, apresentaram uma elevada dispersão, o que sugere uma maior interferência dos efeitos da intra e intervariabilidade nos participantes, bem como das limitações da própria metodologia. É de salientar a muito menor variabilidade dos resultados obtidos com a colorimetria, o que indica que esta metodologia pode ser mais vantajosa na avaliação do eritema.

Num estudo que comparou os resultados obtidos com FLD e com a PTEA em voluntários saudáveis observou-se que apenas com concentrações mais elevadas de LSS se verificou o aumento dos valores de FLD ${ }^{[21]}$. Este facto foi justificado pelo facto de os danos causados pelo surfactante na barreira epidérmica, pela alteração dos lipídos e proteínas do estrato córneo, ocorrerem mais rapidamente que a resposta inflamatória e vascular. No entanto, quando a barreira é danificada de forma mais severa por concentrações elevadas de LSS, a res- 
to observe some differences in the competence of the cutaneous barrier of both groups, since the impact of SLS on these variables was higher in atopic volunteers. There appears to be an increase in cutaneous permeability in the presence of atopic dermal disposition, resulting in the penetration of larger amounts of SLS through $\mathrm{SC}$, and hence a greater inflammatory response ${ }^{[22]}$. However, the differences found did not reach statistical significance, likely due to the lower number of volunteers in the atopic group. It would be desirable to confirm this trend by increasing the size of both participant groups, particularly the atopic.

A study with similar objectives using LDF and TEWL was performed by Bandier et al. ${ }^{[23]}$. As in our study, no differences were found in the baseline TEWL of the volunteers with and without AD. The cutaneous response was compared to the SLS application of 20 healthy volunteers and 38 volunteers with $\mathrm{AD}$ and different types of filaggrin gene mutation. Only statistically significant differences were found after 24 hours of application between healthy volunteers and those with $\mathrm{AD}$ and a filaggrin mutation in the LDF results, whereas for the TEWL there were differences in the groups of volunteers with and without mutation.

In an investigation carried out by Angelova-Fischer et al. ${ }^{[24]}$, the susceptibility to cumulative application (during five days) of SLS and / or aqueous solution of $\mathrm{NaOH}$ was observed by colorimetry and TEWL. Twenty volunteers with $\mathrm{AD}$ and 20 healthy volunteers participated in this study. After five days of exposure to the different agents, no differences in a $*$ results were observed in volunteers with and without AD. For the TEWL, although higher values were recorded in each day in the patients with AD, only statistically significant differences were reached on Day 5 .

Although based on a small number of atopic volunteers, this study confirms the interest of the SLS-based model as a good way to assess skin barrier function in both healthy and atopic subjects and that measurement of erythema by colorimetry can be used as a measure to support the robustness of TEWL results.

\section{Acknowledgements}

This work is financed by national funds through the posta inflamatória é mais intensa, sendo então possível constatar as mudanças pela fluxometria ${ }^{[21]}$.

No presente estudo, a comparação entre os valores médios de PTEA, de eritema quantificado por colorimetria $\left(\mathrm{a}^{*}\right)$ e de FLD permite observar algumas diferenças na competência da barreira cutânea dos dois grupos, já que o impacto do LSS nestas variáveis foi maior nos voluntários atópicos. Parece haver um aumento da permeabilidade cutânea na presença de disposição cutânea atópica, resultando na penetração de maiores quantidades de LSS através do SC, e logo numa maior resposta inflamatória ${ }^{[22]}$. No entanto, as diferenças encontradas não atingiram significância estatística, muito provavelmente devido à menor quantidade de voluntários no grupo de atópicos Seria desejável confirmar esta tendência alargando os resultados dos dois grupos, particularmente dos atópicos.

Um estudo com objectivos semelhantes usando FLD e PTEA foi realizado por Bandier et al ${ }^{[23]}$. Também não foram encontradas diferenças na PTEA basal dos volutários com e sem DA. Foi comparada a resposta cutânea à aplicação de LSS de 20 voluntários saudáveis e de 38 voluntários com DA e diferentes tipos de mutação do gene da filagrina. Apenas foram encontradas diferenças estatisticamente significativas após $24 \mathrm{~h}$ de aplicação entre os volutários saudáveis e aqueles que tinham DA e uma mutação da filagrina nos resultados de LDF, enquanto que para a PTEA observaram-se diferenças nos grupos de volutários com DA com e sem mutação.

$\mathrm{Na}$ investigação realizada por Angelova-Fischer et al ${ }^{[24]}$, foi observada através de colorimetria e PTEA a susceptibilidade à aplicação cumulativa (durante 5 dias) de LSS e/ou solução aquosa de $\mathrm{NaOH}$. Colaboraram neste trabalho 20 voluntários com DA e 20 saudáveis. Após 5 dias de exposição aos diferentes agentes, não foram observadas diferenças nos resultados de $\mathrm{a}^{*}$ obtidos nos voluntários com e sem DA. Para a PTEA, embora tenham sido registados em cada dia do estudo valores superiores nos voluntários com DA, apenas se atingiram diferenças estatisticamente significativas no dia 5 .

Embora baseado num pequeno número de voluntários atópicos, este estudo confirma o interesse do modelo baseado na agressão com LSS, como uma boa forma de avaliar o estado da função de barreira da pele quer em indivíduos saudáveis quer em atópicos e que a medição do eritema, por colorimetria pode ser usada como medida de suporte à robustez dos resultados de PTEA.

\section{Agradecimentos}

Este trabalho é financiado por fundos nacionais através 
FCT - Foundation for Science and Technology, I.P., under the project UID / DTP / 04567/2019.

\section{Conflict of interest}

The authors declare that there is no financial or personal relationship that might be perceived as posing a potential conflict of interest da FCT - Fundação para a Ciência e Tecnologia, I.P., através do projecto UID / DTP / 04567/2019.

\section{Conflito de Interesses}

Os autores declaram não existir qualquer relação pessoal ou financeira que possa ser entendida como representando um potencial conflito de interesses.

\section{References / Referências}

[1] Ritcher T, Peuckert C, Sattler M, et al. Dead but highly dynamic - the Stratum corneum is divided into three hydration zones, Skin Pharmacol Physiol 2004; 17: 246-257.

[2] Proksch E, Fölster-Holst R, Bräutigam M, et al. Role of the epidermal barrier in atopic dermatitis. J Dtsch Dermatol Ges 2009; 10: 899-910. isçp:

[3] Chilcott, RP, Dalton, CH, Emmanuel, AJ, et al..Transepidermal water loss does not correlate with skin barrier function in vitro, J Invest Dermatol 2002; 118: 871-875

[4] Polańska A, Dańczak-Pazdrowska A, Silny W, et al. Evaluation of selected skin barrier functions in atopic dermatitis in relation to the disease severity and pruritus. Postep Derm Alergol 2012; 29: 373-377.

[5] Polańska A, Dańczak-Pazdrowska A, Silny W, et al. Nonlesional skin in atopic dermatitis is seemingly healthy skin - observations using noninvasive methods. Wideochir Inne Tech Maloinwazyjne 2013; 8(3):192-199.

[6] Kim BE, Leung DYM. Significance of Skin Barrier Dysfunction in Atopic Dermatitis. Allergy Asthma Immunol Res. 2018; 10(3): $207-215$.

[7] Frosch PJ, Wissing C. Cutaneous sensitivity to ultraviolet light and chemical irritants. Arch Dermatol Res 1982;272(3-4):269-278.

[8] Rosado C, Ferreira J, Pinto PC, Rodrigues LM. Skin Barrier Function Evaluation by Bi-compartmental Analisys of TEWL Dynamical Measurements: Validation of New Analytical Conditions. Biomed Biopharm Res 2012; (9) 2: 183-189

[9] Kim DW, Park JY, Na GY, Lee SJ, Lee WJ. Correlation of clinical features and skin barrier function in adolescent and adult patients with atopic dermatitis Int J Dermatology 2006: 45, 698-701.

[10] Belsito, DV. Occupational contact dermatitis: etiology, prevalence, and resultant impairment/disability. J Am Acad Dermatol 2005; 53: 303-313.

[11] Wahlberg JE, Maibach HI. Nonanoic acid irritation - a positive control at routine patch testing. Contact Dermatitis 1980; 6:128-130.

[12] Held E, Agner T. Comparison between 2 test models in evaluating the effect of a moisturizer on irritated human skin. Contact Dermatitis 1999; 40: 261-268.

[13] Rogiers V. EEMCO guidance for the Assessment of the Transepidermal Water Loss (TEWL) in Cosmetic Sciences. Skin Pharmacol Physiol 2001; 14:117-128.

[14] Gloor M, Senger B, Langenauer M, et al.. On the course of the irritant reaction after irritation with sodium lauryl sulphate. Skin Res Technol 2004; 10 : 144-148.

[15] Bircher AJ, de Boer EM, Agner T, Wahlberg JE, et al. Guidelines for the measurement of cutaneous blood flow by laser Doppler flowmetry. Contact Dermatitis 1994; 30:65-72.

[16] Fullerton AQ, Fisher T, Lahti, AQ, et al. Guidelines for the measurement of skin color and erythema, Contact Dermatitis 1996; 35:1-10.

[17] de Oliveira CA, Peres DD, Rugno CM, Kojima M, de Oliveira Pinto C.S, Consiglieri VO, Kaneko TM, Rosado C, Mota J, Velasco MVR, Baby AR. Functional photostability and cutaneous compatibility of bioactive UVA sun care products. J Photochem Photobiol B Biol 2015;148:154-159.

[18] Pinnagoda J, Tupker R A, Agner T, Serup J. Guidelines for transepidermal water loss (TEWL) measurements. Contact Dermatitis 1990; 22: 164-178.

[19] Thomas CL, Fernández-Peñas P. The microbiome and atopic eczema: More than skin deep. Australas. J Dermatol 2017; 58:18-24.

[20] Makrgeorgou A, Leonardi-Bee J, Bath-Hextall FJ, Murrell DF, Tang ML, Roberts A, Boyle RJ. Probiotics for treating eczema. Cochrane database Syst. Rev. 2018. 11, CD006135.

[21] Aramaki J, Effendy I, Happle R, et al. Which bioengineering assay is appropriate for irritant patch testing with sodium lauryl sulfate? Contact Dermatitis 2001; 45:286-290.

[22] Jakasa I, de Jongh CM, Verberk MM, Bos JD, Kezic S. Percutaneous penetration of sodium lauryl sulphate is increased in uninvolved skin of atopic dermatitis patients compared to control subjects. Br J Dermatol 2006; 155:104-109.

[23] Bandier J, Carlsen BC, Rasmussen MA, Petersen LJ, Johansen JD. Skin reaction and regeneration after single sodium lauryl sulfate exposure stratified by filaggrin genotype and atopic dermatitis phenotype. Br J Dermatol 2015; 172: 1519-1529.

[24] Angelova-Fischer I, Dapic I, Hoek AK, Jakasa I, Fischer TW, Zillikens D, Kezic S. Skin barrier integrity and natural moisturising factor levels after cumulative dermal exposure to alkaline agents in atopic dermatitis. Acta Derm Venereol 2014; 94: 640-644. 